
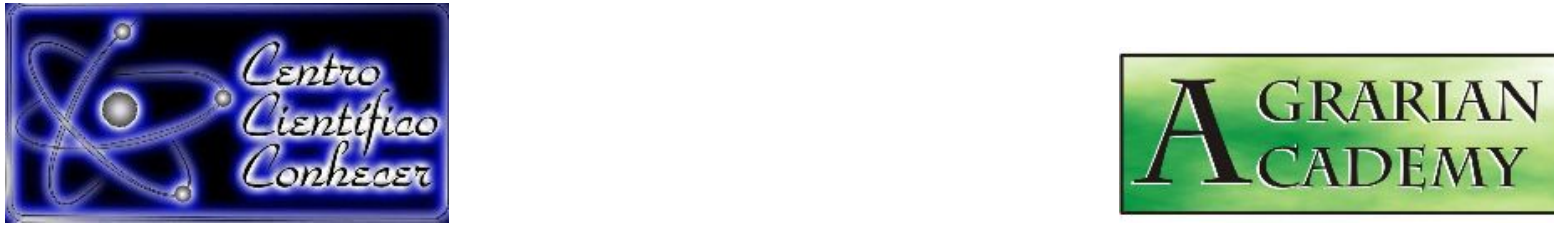

\title{
MORPHOLOGICAL PARAMETERS IN CLONAL SEEDLINGS OF Eucalyptus spp. IN THE EXPEDITION PHASE
}

\author{
João Faustino Munguambe ${ }^{1}$, Oclizio Medeiros das Chagas Silva², Inês Sebastão \\ Chelene $^{3}$, Mateus José Comé ${ }^{4}$, Nelson Venturin ${ }^{5}$
}

1. Forest Engineer, Doctorate in Forest Engineering - Department of Forest Sciences Federal University of Lavras /UFLA - Cx.P. 3037 - 37200-000 - Lavras, State of Minas Gerais, Brazil. (omflorestal@hotmail.com)

2. Master in Forest Engineering at Federal University of Lavras, Brazil

3. Biologist, Master in Forest Sciences - Agricultural Research Institute of Mozambique (IIAM)

4. Agronomy Engineer, Master in Plant Pathology - Cashew Promotion Institute (INCAJU), Mozambique

5. Retired Professor of the Department of Forest Sciences, Federal University of Lavras, Brazil

Recebido em: 14/07/2018 - Aprovado em: 28/07/2018 - Publicado em: 31/07/2018

DOI: 10.18677/Agrarian_Academy_2018a39

\begin{abstract}
The seedlings production process of forest plant species is found to be an important stage in the forest-based production chain. The present work was conducted in commercial nurseries aiming to assess morphological parameters of Eucalyptus clonal seedlings in the expedition phase. The experiment was performed in two nurseries located in the southern part (Nursery \#1) and slopes' field (Nursery \#2) of the State of Minas Gerais, Brazil. The Completely Randomized Design was used, with four treatments or clones (AEC 144 - Eucalyptus urophylla, AEC 244 Eucalyptus urophylla, AEC 1528 - hybrid of E. urophylla x Eucalyptus grandis and AEC 100 - hybrid of $E$. urophylla $x E$. grandis), seven replications and 16 seedlings per plot. Seedlings were produced in $54 \mathrm{~cm}^{3}$ tubetes according to nurseries protocols. The following parameters were assessed: plant height, collar diameter, dry matter, and seedlings quality index. The Sisvar statistical analysis system was run for Analysis of Variance, and averages were compared by means of Scott-Knott test at $5 \%$ significance. The clone AEC 1528 showed better quality standards at the Nursery $\# 1$, and clones AEC 100 and AEC 244 showed greater height and collar diameter at the Nursery \#2. Therefore, seedlings from commercial nurseries under study showed adequate morphological quality standards for expedition and planting.
\end{abstract}

KEYWORDS: Growth, Quality of seedlings, Quality index. 


\title{
PARÂMETROS MORFOLÓGICOS EM MUDAS CLONAIS DE Eucalyptus spp. NA FASE DE EXPEDIÇÃO
}

\begin{abstract}
RESUMO
O processo de produção de mudas de espécies florestais é uma etapa importante na cadeia de produção florestal. O presente trabalho foi conduzido em viveiros comerciais com o objetivo de avaliar parâmetros morfológicos em mudas clonais de eucalipto na fase de expedição. O experimento foi conduzido em dois viveiros florestais localizados nas regiões sudoeste (Viveiro 1) e campo das vertentes (Viveiro 2) do estado de Minas Gerais, Brasil. O delineamento experimental utilizado foi o inteiramente casualizado com quatro clones (AEC 144-Eucalyptus urophylla, AEC 244-Eucalyptus urophylla, AEC 1528- híbrido de Eucalyptus urophylla $\times$ E. grandis e AEC 100-híbrido de Eucalyptus urophylla $\times$ E. grandis), com sete repetições e 16 mudas por parcela. As mudas foram produzidas em tubetes de $54 \mathrm{~cm}^{3}$, seguindo o protocolo dos viveiros. Foram avaliadas as características morfológicas: altura, diâmetro do colo, matéria seca e índice de qualidade das mudas. O sistema de análise estatística do Sisvar foi executado para Análise de Variância, e as médias foram comparadas por meio do teste de Scott-Knott a 5\% de significância. O clone AEC 1528 apresentou melhores padrões de qualidade no Viveiro \# 1, e os clones AEC 100 e AEC 244 apresentaram maior altura e diâmetro de colo no Viveiro \# 2. Portanto, mudas de viveiros comerciais em estudo apresentaram padrões de qualidade morfológica adequados para expedição e plantio.
\end{abstract}

PALAVRAS- CHAVE: Crescimento, Qualidade de mudas, Indice de qualidade.

\section{INTRODUCTION}

The forest-based sector value chain has been highlighted in the supply of products and by-products to attend the demand for energy, paper and cellulose wordwide. Nowadays, the brazilian sector for artificial forests is found to be the most important segment of the production chain in global scenario. The current planted area is estimated at 7.8 million hectares, which is responsible for $91 \%$ of timber produced for industry use in Brazil. Among the existing timber species, Eucalyptus is found to be the most important, since it occupies about $75 \%$ of total planted forest area in the country (ABRAF, 2016).

The prodution of high quality seedlings plays a very important role since seedlings are essencial for forests establishment to attend demand for forest products over time. However, the success in the establishment of forests depends on seedlings morphological quality standards. These characteristics allow them to resist against adverse climate conditions after planting and to result in forest plants with economically desirable volumetric growth (GOMES et al., 2002; AFONSO et al., 2017).

Morphological characters have been used to guide the seedlings prodution process and planting (CARLOS et al., 2014). However, nursery men do not usually follow any standard in the selection process of seedlings for planting, due to lack of technical normative protocols to operate nurseries (DA ROS et al., 2015).

Brazilian forest companies describe high quality Eucalyptus seedlings as follows: plants height ranging from 25 to $30 \mathrm{~cm}$, collar diameter greater than $2 \mathrm{~mm}$, aggregated and well-developed root system, rigid stem, at least three pair of leaves, 
branching, vigour and absence of diseases symptoms (GOMES et al., 2002). These characteristics are also affected by management pactices such as seedlings density in the nursery, pruning, weeding within vases, control of pests and diseases, level of mycorrhiza colonization, fertility of the substrate used to fill plastic bags, and other practices (CARNEIRO, 1995). In addition, some of quality standards described in the literature had been tested for seedlings survival and growth after planting, and results show that seedlings performance vary even for high quality seedling and/or grown under good environmental and management conditions (FERNANDES et al., 2016).

The Dickson quality index (DQI) has also been used as a useful biometric parameters for seedlings quality assessment (DICKSON et al., 1960). However, seedlings must be harvested and destroyed in this process, which makes this procedure not practicable for most of forest companies due to time loss and high production costs involved in the seedlings production and processing processes.

Therefore, this work was performed in two commercial nurseries located in the State of Minas Gerais, Brazil, aiming to assess morphological parameters of Eucalyptus clonal seedlings in the expedition phase. Technical standards described in this study may be used as normative protocols to operate nurseries and guide forest companies in the seedlings production and selection processes for planting.

\section{MATERIAL AND METHODS}

The experiment was established in two commercial forest nurseries located in the southern part (the Nursery \#1) and the slopes' field mesoregion (the Nursery \#2) both in the State of Minas Gerais, Brazil.The Completely Randomized Design was used, with four clones (AEC 144 - Eucalyptus urophylla, AEC 244 - Eucalyptus urophylla, AEC 1528 - hybrid of E. urophylla x Eucalyptus grandis and AEC 100 hybrid of $E$. urophylla $\times E$. grandis), seven replications and 16 seedlings per plot.

A commercial substrate obtained by mixing pinus bark and vermiculite (CPV formulate, with $30 \%$ coconut fibre) was used to fill conic tubetes. Tubetes consisted of polyethylene conical tubes with $12.5 \mathrm{~cm}$ heigh, $3 \mathrm{~cm}$ diameter of the upper part, 1 $\mathrm{cm}$ hole in the bottom; $54 \mathrm{~cm}^{3}$ volume; and a circular section consisting of six longitudinal and equidistant internal bands. The technique used for seedlings production was according to protocols used in nurseries under study.

At 90 days after planting, 16 seedlings were sampled per plot in the expedition phase. Seedlings were taken from the central part of each tray containing 48 units and used to measure the shoot height $(\mathrm{H})$ by means of a millimeter ruler, and the collar diameter (CD) by means of an eletronic digital calliper. Then, a subset of 8 seedlings was taken from the sample to estimate the shoot dry weight (SDW) and root dry weight (RDW).

To estimate the SDW and RDW, seedlings were harvested and separated into shoots and roots. Roots were washed in running water to remove substrate adhered to them. Then, seedlings were placed on the stand of the Laboratory of Silviculture of the Department of Forest Sciences at UFLA for 24 hours to remove excessive water on the material.

Each sample consisting of shoot or root was put in a separate paper bag and dried in a hothouse at $75^{\circ} \mathrm{C}$ temperature for 72 hours, and then removed when plant material reached constant weight. The total dry matter (TDM) was obtained as the sum of SDW and RDW. The ratio SDW $\div$ RDW and the vigour index $(\mathrm{H} \div \mathrm{CD})$ were also estimated, as well as the Dickson quality index (DQI) given by the following equation: $\mathrm{DQI}=\mathrm{TDM}_{(\mathrm{g})} /\left[\left(\mathrm{H}_{(\mathrm{cm})} / \mathrm{D}_{(\mathrm{mm})}\right)+\left(\mathrm{SDW}_{(\mathrm{g})} / \mathrm{RDW}_{(\mathrm{g})}\right)\right]($ DICKSON et al., 1960). The Sisvar 
v5.3 Statistical Analysis System (FERREIRA, 2011) was run for Analysis of Variance, and averages were compared by means of Scott-Knott test at $5 \%$ significance.

\section{RESULTS AND DISCUSSION}

Table 1 shows significant interaction between nurseries and clones of Eucalyptus for all variables under study $(\mathrm{p}<0.05)$, namely: shoot height $(\mathrm{H})$, collar diameter $(C D)$, vigour index $(H \div C D)$, shoot dry weight (SDW), root dry weight (RDW), total dry matter (TDM), ratio SDW $\div$ RDW, and Dickson quality index (DQI).

TABLE 1. Summary of the joint analysis of variance for all variables under study, in the expedition phase of seedlings of Eucalyptus, 90 days after slips planting

\begin{tabular}{|c|c|c|c|c|c|}
\hline \multirow{2}{*}{ Source of Variation } & \multirow{2}{*}{ DF } & \multicolumn{4}{|c|}{ Mean Squares and Significance of F-test } \\
\hline & & $\mathrm{H}(\mathrm{cm})$ & $\mathrm{CD}(\mathrm{mm})$ & $H \div D C$ & SDW (g) \\
\hline Nursery & 1 & $538.9663^{\star *}$ & $0.0236^{\text {ns }}$ & $100.3393^{\star \star}$ & 12.2953 * \\
\hline Clone & 3 & 16.0079 * & $0.4879 * *$ & $14.7580^{* *}$ & $11.3350^{*}$ \\
\hline Nursery $\times$ Clone & 3 & $298.6800^{\star *}$ & $0.3832^{* \star}$ & $39.9640 * *$ & $23.9955^{\star *}$ \\
\hline Residual & 48 & 3.8849 & 0.0275 & 0.4914 & 1.9239 \\
\hline $\begin{array}{l}\text { Coefficient of } \\
\text { Variation (CV) }\end{array}$ & $\%$ & 6.71 & 6.32 & 6.23 & 14.05 \\
\hline
\end{tabular}

\begin{tabular}{|c|c|c|c|c|c|}
\hline \multirow{2}{*}{ Source of Variation } & \multirow{2}{*}{ DF } & \multicolumn{4}{|c|}{ Mean Squares and Significance of F-test } \\
\hline & & RDW (g) & SDW $\div R D W$ & TDM $(g)$ & DQI \\
\hline Nursery & 1 & $16.9180^{\star \star}$ & $3.4950^{\star \star}$ & $58.0585^{\star \star}$ & $0.0002^{\mathrm{ns}}$ \\
\hline Clone & 3 & $5.2915^{\star \star}$ & $1.4075^{\star \star}$ & $25.6966^{\star *}$ & $0.1914^{\star *}$ \\
\hline Nursery $\times$ Clone & 3 & $2.0448^{*}$ & $1.2322^{\star *}$ & $34.0114^{* *}$ & $0.1876^{* *}$ \\
\hline Residual & 48 & 0.3905 & 0.0875 & 3.4534 & 0.0154 \\
\hline $\begin{array}{l}\text { Coefficient of } \\
\text { Variation (CV) }\end{array}$ & $\%$ & 16.19 & 11.21 & 13.53 & 12.44 \\
\hline
\end{tabular}

DF $=$ degrees of freedom, ${ }^{* *}$ Significant at $1 \%$ probability, ${ }^{\text {ns }}=$ non-significant.

Averages of all parameters under study for seedlings in the expedition phase varied significantly in nurseries under study (Table 2) at $1 \%$ probability. Seedlings of the clone AEC 1528 showed greater height growth in the Nursery \#1, while clones AEC 244 and AEC 100 showed greater height growth in the Nursery \#2. These findings do not differ from those outined in Gomes et al. (2003), which described high quality seedlings of Eucalyptus spp. as seedlings with heigh ranging from $25 \mathrm{~cm}$ to $35 \mathrm{~cm}$ in the expedition phase, thus, ready for distribution and planting.

Regarding the collar diameter (CD), greater estimates were found for clones AEC 144 and AEC 1528 in the Nursery \#1, and clones EAC 100 and EAC 1528 in the Nursery \#2 (Table 2). As described in terms of height growth, the CD was also used as a quality parameter for further seedlings development in this study. However, Sturion et al. (2000) and Gomes et al. (2002) outlined that better seedlings CD should range from $2.0 \mathrm{~mm}$ to $3.5 \mathrm{~mm}$ in the expedition phase. In addition, Gomes et al. (2002) stated that high quality seedlings should show greater CD in the expediton phase, so that seedlings will react better after planting and grow faster.

AGRARIAN ACADEMY, Centro Científico Conhecer - Goiânia, v.5, n.9; p. 4032018 
The CD was also described in Carlos et al. (2015) as one of the most important parameters for seedlings development, and indicates the high seedlings survival capacity after planting.

TABLE 2. Averages of shoot height $(H)$, collar diameter $(C D)$, vigour index $(H \div C D)$, shoot dry weight (SDW), root dry weight (RDW), total dry matter (TDM), ratio SDW $\div$ RDW, and Dickson quality index (DQI) of clonal seedlings of Eucalyptus in the expedition phase, 90 days after slips planting

\begin{tabular}{|c|c|c|c|c|c|c|c|c|}
\hline \multirow{2}{*}{ CLONES } & \multicolumn{2}{|c|}{$\mathrm{H}(\mathrm{cm})$} & \multicolumn{2}{|c|}{$\mathrm{CD}(\mathrm{mm})$} & \multicolumn{2}{|c|}{$H \div D C$} & \multicolumn{2}{|c|}{ SDW (g) } \\
\hline & N\#1 & N\#2 & N\#1 & N\#2 & N\#1 & N\#2 & N\#1 & N\#2 \\
\hline AEC-144 & $26.65 \mathrm{bB}$ & $28.98 \mathrm{bA}$ & $2.79 \mathrm{aA}$ & $2.58 \mathrm{bB}$ & $9.59 \mathrm{bB}$ & $11.23 \mathrm{cA}$ & $9.16 \mathrm{bB}$ & $8.92 \mathrm{bB}$ \\
\hline AEC-244 & $22.77 \mathrm{cB}$ & $36.65 \mathrm{aA}$ & $2.56 \mathrm{bA}$ & $2.33 \mathrm{cB}$ & $8.89 \mathrm{bB}$ & $15.82 \mathrm{aA}$ & $9.76 \mathrm{bB}$ & $11.23 a A$ \\
\hline AEC-100 & $23.45 \mathrm{cB}$ & $37.11 \mathrm{aA}$ & $2.29 \mathrm{cB}$ & $2.75 a A$ & $10.23 a B$ & $13.54 \mathrm{bA}$ & $6.99 \mathrm{cB}$ & $11.31 \mathrm{aA}$ \\
\hline AEC-1528 & $32.15 a A$ & $27.11 b B$ & $2.94 \mathrm{aA}$ & $2.78 \mathrm{aA}$ & $10.92 \mathrm{aA}$ & $9.76 \mathrm{~dB}$ & $11.69 \mathrm{aA}$ & $9.89 \mathrm{bB}$ \\
\hline
\end{tabular}

\begin{tabular}{lccccccccc}
\hline \multirow{2}{*}{ CLONES } & \multicolumn{2}{c}{ RDW $\mathbf{( g )}$} & \multicolumn{2}{c}{ SDW $\div$ RDW } & \multicolumn{2}{c}{ TDM $\mathbf{( g )}$} & \multicolumn{2}{c}{ DQI } \\
\cline { 2 - 9 } & $\mathbf{N \# 1}$ & $\mathbf{N \# 2}$ & $\mathbf{N \# 1}$ & $\mathbf{N \# 2}$ & $\mathbf{N \# 1}$ & $\mathbf{N \# 2}$ & $\mathbf{N \# 1}$ & $\mathbf{N \# 2}$ \\
\hline AEC-144 & $3.69 \mathrm{aB}$ & $3.71 \mathrm{bB}$ & $2.48 \mathrm{cB}$ & $2.39 \mathrm{bB}$ & $12.87 \mathrm{aB}$ & $12.64 \mathrm{bB}$ & $1.06 \mathrm{bA}$ & $0.92 \mathrm{bB}$ \\
AEC-244 & $3.90 \mathrm{aB}$ & $5.54 \mathrm{aA}$ & $2.55 \mathrm{cB}$ & $2.06 \mathrm{bB}$ & $13.67 \mathrm{aB}$ & $16.77 \mathrm{aA}$ & $1.19 \mathrm{aA}$ & $0.93 \mathrm{bB}$ \\
AEC-100 & $2.45 \mathrm{bB}$ & $4.09 \mathrm{bA}$ & $2.85 \mathrm{bA}$ & $2.78 \mathrm{aB}$ & $9.44 \mathrm{bB}$ & $15.40 \mathrm{aA}$ & $0.72 \mathrm{cB}$ & $0.94 \mathrm{bA}$ \\
AEC-1528 & $3.19 \mathrm{aB}$ & $4.28 \mathrm{bA}$ & $3.66 \mathrm{aA}$ & $2.31 \mathrm{bB}$ & $14.88 \mathrm{aB}$ & $14.18 \mathrm{bB}$ & $1.01 \mathrm{bB}$ & $1.17 \mathrm{aA}$ \\
\hline
\end{tabular}

${ }^{*}$ Means followed by the same lower case letter in the column and capital letter in the row do not differ statistically from each other by the Scott-Knott test at $5 \%$ probability. N\#1 = Nursery $\# 1$; and $\mathrm{N} \# 2$ = Nursery \#2.

For vigour index $(\mathrm{H} \div \mathrm{CD})$, clones $\mathrm{AEC} 100$ and $\mathrm{AEC} 1528$ were found to be better in the Nursery \#1, and clones EAC 244 and AEC 100 showed greater ratio "height $\div$ collar diameter" in the Nursery \#2 (Table 2). This index shows plants growth balance over time since it relates two very important variables, height growth and collar diameter, which describe seedlings morphological quality in a given production phase (JOHNSON ; CLINE, 1991; CARNEIRO, 1995). According to Gomes et al. (2002), the vigour index estimate should range from 6 to 10. In addition, they stated that values greater than 10 may affect seedlings quality and survival after planting since plants will be very tall, with fine stem, however, likely to tip over in cases of occurrence of field winds.

The shoot dry weight (SDW) also varied in both Nurseries. The clone AEC 1528 was found to be better in the Nursery \#1 and clones EAC 244 and AEC 100 showed greater SDW estimates in the Nursery \#2 (Table 2). Bellote and Silva (2000) described the SDW as a very important parameter for seedlings quality assessment AGRARIAN ACADEMY, Centro Científico Conhecer - Goiânia, v.5, n.9; p. 4042018 
since it provides information in terms of capacity for photosynthesis, which will result in better plants growth over time.

Regarding the root dry weight (RDW), most of clones under study performed well in the nursery, although statistically significant differences were also found $(p<0.01)$ between treatments (clones). According to Freitas et al. (2017) and Delarmelina et al. (2013), greater estimates of RDW mean better seedlings performance after planting, since the root system will be able to better anchor the seedling, allow better water and minerals absorption, and easly translocate water and minerals to stem. Thus, seedlings with lesser RDW estimates may reduce plants growth speed and increase costs for plantations maintainance over time (BEHLING et al., 2014; LOPES et al., 2016; FREITAS et al., 2017).

The ratio $S D W \div R D W$, which is described here as the efficiency index for seedlings development, varied significantly at 1\% probability. Clones EAC 1528 and AEC 100 showed better estimates in nurseries under study (Table 2). Gomes et al. (2002) also described the ratio SDW $\div$ RDW as a great parameter to assess seedlings quality, and Brissette (1984) apud Cruz et al. (2009) established that a SDW $\div$ RDW equal to 2.0 refers to high quality seedlings for planting.

Regarding the total dry matter (TDM), estimates varied within nurseries for clones AEC 100 (Nursery \#1), and AEC 144 and AEC 1528 (Nursery \#2). In addition there was a significant variation within clones for both nurseries, only for clones $A E$ 244 and AEC $100(p<0.01)$. In fact, the TDM indicates good seedlings resistance capacity under field conditions after planting, acoording to Gomes et al. (2003).

The Dickson quality index (DQI) is described here as a cross-cutting factor used to assess morphological characteres of seedlings of Eucalyptus spp. According to Gomes et al. (2002) the more is the DQI, the seedling quality will be better, as well as their response after planting. Then, high performing plants after planting contain greater DQI estimates.

Therefore, the used of a set of parameters to assess morphological quality of Eucalyptus clonal seedlings is found to be more informative than assessing a single parameter. Freitas et al. (2017) described the same, considering that various parameters allow nursery manegers to better choose seedlings that will perform better after planting. Tsukamoto-Filho et al. (2013) and Lopes et al. (2014) also refer to the management practices needed for plantations maintenance and related costs. In addition, a high quality seedling means hight timber production capacity, which is described in Silveira et al. (2013) and Faria et al. (2013) as the main goal of any forest company in the world.

\section{CONCLUSION}

The clone AEC 1528 showed better quality standards at the Nursery \#1, and clones AEC 100 and AEC 244 showed greater height and collar diameter at the Nursery \#2, which means high quality seedlings and further vigour and development.

Eucalyptus clonal seedlings from commercial nurseries under study showed adequate morphological quality standards for expedition and planting.

\section{REFERENCES}

AFONSO, M. V.; MARTINAZZO, E.; G.; AUMONDE, T.; Z.; VILLELA, F.; A. Parâmetros fisiológicos de mudas de Albizia niopoides produzidas em diferentes composições de substrato. Ciência Florestal, Santa Maria, v. 27, n. 4, p. 1395 1402 , 2017. Available at: 
<https://periodicos.ufsm.br/cienciaflorestal/article/view/30221.> doi:http://dx.doi.org/10.5902/1980509830221

ABRAF - Associação Brasileira de produtores de florestas plantadas. Anuário estatístico da ABRAF 2017, ano base 2016. Brasília, p.152, 2015.

BEHLING, M. NEVES, J. C. L.; DE BARROS, N. F.; KISHIMOTO, C. B.; SMIT, L. Eficiência de utilização de nutrientes para formação de raízes finas e médias em povoamento de teca. Revista Árvore, Viçosa, MG, v. 38, n. 5, p. 837-846, 2014. Available at: < http://ainfo.cnptia.embrapa.br/digital/bitstream/item/115315/1/cpamt2014-behling-raizes-teca.pdf> http://dx.doi.org/10.1590/S0100-67622014000500008.

BELLOTE, A. J. F.; SILVA, H. D. Técnicas de amostragem e avaliações nutricionais em plantios de Eucalyptus spp. In: GONÇALVES, J. L. M.; BENEDETTI, V. (Ed.). Nutrição e fertilização florestal. Piracicaba: IPEF, p. 135-166. 2000.

CARLOS, L.; VENTURIN, N.; MACEDO, R. L. G.; HIGASHIKAWA, E. M.; GARCIA, M. B. et al. Crescimento e nutrição mineral de mudas de pequi sob efeito da omissão de nutrientes. Ciência Florestal, Santa Maria, v. 24, n. 1, p. 13-21, jan.-mar., 2014. Available at: http://www.scielo.br/scielo.php?pid=S1980$50982014000100013 \&$ script=sci_abstract\&tlng=pt.

CARLOS, L.; VENTURIN, N.; FARIAS, E. S.; VENTURIN, R. P.; MACEDO, R. L. G. Growth and mineral nutrition in seedlings of jacarandá-da-bahia subjected to nutrient deprivation. Floresta, Curitiba, v. 45, n. 1, p. 107 - 116, 2015. Electronic ISSN 1982 4688 / ISSN printed 0015-3826. Doi: 10.5380/rf.v45i1.34312.

CARNEIRO, J. G. de A. Produção e controle de qualidade de mudas florestais. Curitiba: UFPR/FUPEF, p. 451, 1995.

CRUZ, C. A. F.; DE PAIVA, H. N.; NEVES, J. C. L.; DA CUNHA, A. C. M. C. M. Resposta de mudas de Senna macranthera (DC. EX Collad.) H.S. Irwin \& Barnaby (Fedegoso) cultivadas em latossolo vermelho amarelo distrófico a macronutrientes. Revista Árvore, Viçosa, MG, v. 34, n. 1, p. 13-24, jan./feb. 2009. ISSN 0100-6762. http://dx.doi.org/10.1590/S0100-67622010000100002.

DA ROS. C. O.; REX, F. E.; RIBEIRO, I. S.; KAFER, P. S.; RODRIGUES, A. C. et al. Uso de Substrato Compostado na Produção de Mudas de Eucalyptus dunnii e Cordia trichotoma. Floresta e Ambiente, v. 22, p. 549-558, 2015. Available at: <http://www.scielo.br/pdf/floram/v22n4/2179-8087-floram-2179-8087115714.pdf>.

Doi: http://dx.doi.org/10.1590/2179-8087.115714.

DELARMELINA. W. M.; CALDEIRA, M. V. W.; FARIA, J. C. T.; GONÇALVES, E. O. Uso de lodo de esgoto e resíduos orgânicos no crescimento de mudas de Sesbania virgata (Cav.) Pers ${ }^{1}$. Revista Agro@mbiente Online, v. 7, n. 2, p. 184-192, mayaugust, 2013. Available at: < https://revista.ufrr.br/agroambiente/article/view/888>. Doi: http://dx.doi.org/10.18227/1982-8470ragro.v7i2.888.

DICKSON, A.; LEAF, A. L.; HOSNER, J. F. Quality appraisal of white spruce and white pine seedling stock in nurseries. Forestry Chronicle, Ottawa, v. 36, n. 1, p. 1013, 1960.

FARIA, J. C. T.; CALDEIRA, M. V. W.; DELARMELINA, W. M.; GONÇALVES, E. O. Uso de resíduos orgânicos no crescimento de mudas de Mimosa setosa. Pesquisa 
florestal brasileira, Colombo, v. 33, n. 76, p. 411-420, out./dez. 2013. Available at: <https://pfb.cnpf.embrapa.br/pfb/index.php/pfb/article/view/501> doi: 10.4336/2013.pfb.33.76.501

FERNANDES, A.; R.; CARVALHO, J.;G.; PAIVA, H.; N.; MIRANDA, J.; R.; P. Efeito do fósforo e do zinco sobre o crescimento de mudas de freijó (Cordia goeldiana Huber.). Revista de Ciências Agrárias/Amazonian Journal of Agricultural and Environmental Sciences, [S.I.], n. 37, p. 123-131, feb. 2016. Available at: $<$ https://ajaes.ufra.edu.br/index.php/ajaes/article/view/2273>.

FERREIRA, D. F. SISVAR software: version 5.3. Lavras: Editora da UFLA, 2011.

FREITAS, E. C. S.; PAIVA, H.; N.; LEITE, H.; G.; NETO, S. N. O. Crescimento e qualidade de mudas de Cassia grandis Linnaeus F. em resposta à adubação fosfatada e calagem. Ciência Florestal, Santa Maria, v. 27, n. 2, p. 509-519, 2017. Available at: https://periodicos.ufsm.br/cienciaflorestal/article/view/27732: doi: http://dx.doi.org/10.5902/1980509827732

GOMES, J. M.; COUTO, L.; LEITE, H. G.; XAIVER, A.; GARCIA, S. L. R. Crescimento de mudas de Eucalyptus grandis em diferentes tamanhos de tubetes e fertilização N-P-K. Revista Árvore, Viçosa, MG, v. 27, n. 1, p. 113-127, 2003. Available $\quad$ at: $\quad h t t p: / / w w w . s c i e l o . b r / s c i e l o . p h p ? p i d=\$ 0100-$ $67622003000200001 \&$ script=sci_abstract\&tlng=pt.

GOMES, J. M.; COUTO, L.; LEITE, H. G.; XAIVER, A.; GARCIA, S. L. R. Parâmetros morfológicos na avaliação da qualidade de mudas de Eucaliptus grandis. Revista Árvore, Viçosa, MG, v. 26, n. 6, p. 655-664, 2002. Available at: http://www.scielo.br/pdf/rarv/v26n6/a02v26n6.pdf. http://dx.doi.org/10.1590/S0100-67622002000600002.

JOHNSON, J. D.; CLINE, P. M. Seedling quality of southern pines. In: DUREYA, M. L.; DOUGHERTY, P. M. (Ed.). Forest regeneration manual. Dordrecht: Kluwer Academic, $\quad$ p. 143-162, $1991 . \quad$ Available at: https://www.researchgate.net/profile/Steve_Grossnickle/publication/321110109_See dling_Quality_of_Southern_Pines_Influence_of_Plant_Attributes/links/5a0dde8e4585 1541b7079be8/Seedling-Quality-of-Southern-Pines-Influence-of-Plant-Attributes.pdf.

LOPES, E. D.; AMARAL, C. L. F.; NOVAES, A. B. Parâmetros morfofisiológicos na avaliação da qualidade de mudas de três espécies florestais. Revista Agrogeoambiental, Pouso Alegre, v. 8, n. 3, p. 51-59, 2016. Doi: http://dx.doi.org/10.18406/2316-1817v8n32016834.

LOPES, E. D.; AMARAL, C. L. F.; NOVAES, A. B. Desempenho no campo de mudas de Eucalyptus urophylla, Eucalyptus camaldulensis e Corymbia citriodora produzidas em diferentes recipientes. Revista Floresta, v. 44, n. 4, p. 589-596, 2014. Available at <https://revistas.ufpr.br/floresta/article/view/26480>. Doi:http://dx.doi.org/10.5380/rf.v44i4.26480.

SILVEIRA, C. E. S.; PALHARES, D.; PEREIRA, L. A. R.; PEREIRA, K. B. D.; SILVA, F. A. B. Strategies of plant establishment of two Cerrado species: Byrsonima basiloba Juss. (Malpighiaceae) and Eugenia dysenterica Mart. ex DC (Myrtaceae). Plant Species Biology, Hoboken, v.28, n.2, p.130-137, 2013. 
STURION, J. A.; GRAÇÃ, L. R.; ANTUNES, J. B. M. Produção de mudas de espécies de rápido crescimento por pequenos produtores. Colombo: Embrapa Florestas, 2000. 20 p. (Circular Técnica, 37).

TSUKAMOTO FILHO, A. De A.; CARVALHO, J. L. O.; DA COSTA, R. B.; DALMOLIN, A. C.; BRONDANI, E. B. Regime de regas e cobertura de substrato afetam o crescimento inicial de mudas de Myracrodruon urundeuva. Floresta e Ambiente, v.20, p. $\quad 521-529$. 2013. Available at: www.scielo.br/scielo.php?script=sci_arttext\&pid=S0034-737X2017000100001. 